\title{
Ideological Manipulation in Twitter Communication: A Critical Stylistic Analysis of Donald Trump's Tweets
}

https://doi.org/10.33806/ijaes2000.22.1.16

\author{
Gibreel Sadeq Alaghbary \\ Qassim University, KSA \\ Taiz University, Yemen
}

Received on 20.4.2021

Accepted on 4.10.2021

Published on 1.1.2022

\begin{abstract}
Donald Trump's use of Twitter as a modality to defame opponents, antagonize media outlets and even glorify violence is an enduring legacy for political campaigns, presidential rhetoric and argumentative debates. This nontraditional use of social media as a political communication tool has invited Twitter's fact-checking editorial decisions, alienated some of Trump's supporters and attracted worldwide criticism. Using purposive sampling, the present paper employs the ten textual-conceptual functions of critical stylistics to analyze a dataset of Trump's tweets on domestic and international political issues published between 2011 and 2020 and assembled from the monitor corpus Trump Twitter Archive. The critical stylistic analysis aims at uncovering Trump's ideological outlook by identifying the extra layer of meaning in which the ideological evaluation is structured and exposing the way in which the resources of language are strategically deployed to influence and ideologically manipulate Trump's followers' experience of reality. Analysis reveals a network of lexical, syntactic, semantic and pragmatic choices underlying Trump's seemingly simple rhetoric. It signposts his ideological evaluation and constructs a world for his followers to desire, believe or fear. The study extends the application of critical stylistics to microblogging channels, with implications both for the linguistic make-up of political communication in Web 2.0 contexts and for the explanatory power of critical stylistics.
\end{abstract}

Keywords: critical stylistics, Donald Trump, political communication, social media, Twitter

\section{Introduction}

The introduction of smartphones in the first decade of the century has made us rely on the internet as the primary means of communication. The affordances of the smartphone, mainly the portability, size, internet access, and touch screen, have made smartphone-mediated communication the preferred and most used communication mode today. The development of hand-held, and subsequently wearable, technology has accelerated the proliferation of online communication and facilitated the exchange of information. It may now be claimed with little reservation that smartphone-mediated communication has superseded traditional and computer-mediated forms of communication.

Smartphone-mediated communication has also facilitated the growth of the participatory social web, also known as Web 2.0, in the early years of the twentyfirst century. Web 2.0 tools, such as video-sharing websites, social networking platforms, and microblogging tools have enabled users to interact with content 
creators and participate in the creation of content. These affordances of Web 2.0 contexts, particularly social networking and microblogging platforms, have democratized online communication, making it interactive and participatory. The change from static communication to dynamic interaction has drawn in businesses and industries that have capitalized on these affordances to market their products and services to a broader audience across the world. The successful adoption of social media as an effective marketing platform has attracted politicians who are increasingly using social media as a political communication tool.

The ubiquitous presence of social networking sites and microblogging tools have made them popular communication media in democratic politics. Twitter, like other Web 2.0 tools, allows users to receive regular updates about political events, interact with political figures, react to political news, engage in political activities, and even contribute political content. In other words, it gives users agency. It also allows political figures to reach out to a broader audience, publicize campaign promises, mobilize supporters, organize political events, and even recruit volunteers. The new media has, therefore, enabled wider public participation in political activity, facilitated reciprocal and interactive political communication, and increased the levels of political literacy among citizens and the accountability of politicians to the public.

One of the earliest and most notable uses of social networking sites as a medium for political communication and activity is the 2008 U.S. presidential elections. Capitalizing on the social media momentum, Barack Obama used Facebook and Twitter as campaign media to reach out to, and engage, the American youth and develop a team of empowered, online volunteers nationally and a growing network of supporters internationally. Obama's success, and subsequent international popularity, encouraged politicians worldwide to use social media for political communication and voter mobilization (Bimber, 2014).

More recently, President Donald Trump has been pushing the limits of the political role of the new media. Trump's trajectory is different, however. Enli (2017) describes Trump's campaign in the 2016 presidential election as having diverged from presidential election campaign norms and describes Trump's style as a "counter-trend in political communication" (50). The present study seeks to uncover the textual choices that constitute Trump's political style and explain the way these choices construct, or propagate, consciously intended ideologies that are designed to influence, and ideologically manipulate, the ideological outlook of his audience.

\section{Previous studies on Trump's Twitter discourse}

Donald Trump's use of social media as a political and campaigning tool has been the subject of a growing body of research. Two research trends are identifiable: one that focuses on Trump's language use in political communication and another that focuses on his tweeting behavior. The former trend focuses largely on the linguistic features of Trump's unconventional political style and the latter on the sentiments generated by and generating from Trump's controversial tweets. 
Research on Trump's political style has identified unique neologisms discursively employed in his political communication (Holubnycha, Kostikova, Besarab, Moshtagh, Lushchyk and Dolgusheva, 2020), strong language, violent expressions and a high incidence of metaphoric dysphemistic expressions, especially in reference to the Covid-19 pandemic (Olimat, 2020), a high frequency of "first-person pronouns (I-talk)", "non-standard and low-complexity words" (Ahmadian, Azarshahi and Paulhus 2017), and an unusual frequency of repetition, intensifiers and metaphors in Trump's political discourse (Garcìa, 2018). Researchers have also examined the readability level of Trump's language and revealed interesting patterns. Wang and Liu (2018) conclude that Trump's language in debates features simple sentences and less diverse vocabulary but a richer vocabulary and more complex sentences in campaign speeches. The study concludes that Trump's language shows a readability level close to fifth-grade in debates and at ninth grade in campaign speeches. Kayam (2018) also concludes that Trump speaks at "a fourth- to fifth-grade level" (86), which is a "readability level that is lower than the level of the average adult in the US" (74). These linguistic features of Trump's political style are, at least partly, responsible for Trump's domination of his more experienced Republican presidential nominees (Ahmadian, Azarshahi and Paulhus, 2017) and his popularity among middle and lower-class Americans (Garcìa, 2018). Kayam (2018) adds that Trump's anti-intellectual political communication, evident in the low readability and language simplicity, makes him "understood by almost every American voter" (74).

The other research trend has focused on Trump's tweeting behavior. Using computational tools and a non-probability sample of 300 tweets for manual analysis, Elayan, Sykora and Jackson (2020) explore the topics and functions of Trump's tweets between 29 May and 10 July 2017. The study shows that Trump uses "accusations as a functional communicative tool", reveals "a higher percentage of emotionally charged language use than average", and concludes that the more Trump mixes functional expressions "such as accusation, blame, or expressions of intent", "the more frequently the tweet gets retweeted" (29). Trump's tweeting is predominantly negative (Gorss and Johnson 2016) and these tweeting patterns, especially when channelled at rival democrats, generate the most likes and retweets. His tweeting negativity has been found to "inspire hatred and violence" and promote such ideologies as "sexism, racism, homophobia, and xenophobia" and spread "like a social cancer" (Ott, 2016:64).

The present study relates to the two research trends on Trump. It seeks to systematically uncover the patterns of language in Trump's tweets. This includes lexical choice, syntactic patterning, and meanings communicated overtly via lexical means or covertly using implicatures, assumptions, negation and modality, speech and thought narration, and deictic expressions. It also seeks to explain the way Trump's use of these language patterns achieves the intended effect. The study extends the literature on Trump's communication style and offers new insights, particularly with reference to the exploration of insideous ideological content and ideological manipulation in microblogging platforms. 


\section{Conceptual framework}

Critical stylistics provides the conceptual framework for the present study. The framework, introduced by Lesley Jeffries (2010, 2013, 2014, 2015), offers a toolkit for the investigation of implicit ideologies in virtually all text types. The critical stylistic concern with ideological content in texts is in fact a continuation of a scholarly tradition and research trend started by critical linguists in the 1970s and developed later by critical discourse analysts. What these three frameworks have in common is an interest in exploring "the precise ways in which texts may transmit, reinforce or inculcate ideologies in their readers" (Jeffries, 2010:12). The analytical apparatus of the three frameworks is also largely drawn from Halliday's systemic functional grammar.

Critical stylistics, however, sets itself apart from its forerunners in two significant ways, which warrant its adoption as a conceptual framework in this study. First, language-based analysis is central to critical stylistic studies. While critical discourse analysis, for example, ultimately seeks to explain "how texts fit into the socio-political landscape in which they are produced and read" (Jeffries, 2010:11), which is the last stage in Fairclough's (1989) three-stage model of critical discourse analysis, critical stylistics is more interested in the first two stages of description and interpretation. Secondly, and more relevantly, critical stylistics offers a more coherent analytical toolkit for the investigation of insidious ideological content. Jeffries argues that the analytical device of critical discourse analysis is "incomplete" (Jeffries, 2010:12) and that the toolkit of critical linguistics is "lacking in comprehensive coverage of linguistic features" (13). Jeffries' tenfunction toolkit includes the Hallidayan concepts of transitivity, modality, lexicalization, nominalization and information focus, which are central to the analytical toolkits of critical linguists and critical discourse analysts. The list also includes negation (Nahajec 2009), speech and thought presentation (Semino and Short 2004), and implicatures (Grice, 1975). This makes critical stylistics a more comprehensive and more coherent framework for exposing ideological slant in texts.

The tools making up the analytical toolkit of critical stylistics are called textual-conceptual functions (Jeffries, 2010). The name that Jeffries selects is descriptive. These textual-conceptual functions (henceforth TCFs) are textual features that carry conceptual functions. The features are linguistic triggers that denote conceptualizations about the world. All the TCFs are in the participle form (e.g., naming vs. nominalization and hypothesizing vs. modality), which Jeffries argues is a "deliberate" choice" as it answers that question (what is the text doing?)" and avoids the technical meta-language permeating the literature (Jeffries, 2015:164). The ten TCFs cover linguistic choice at the lexical, morphological, syntactic, semantic and pragmatic levels of language.

The first TCF is naming and describing, which involves the choice of nouns, nominalized verbs, and noun phrases to communicate and naturalize ideologies. This function is instantiated lexically by naming and the choice of ideologically loaded nouns and adjectives. It is also morphologically carried by nominalization, which involves turning a process into a thing in order to package ideologically 
evaluative verbs into the head of a nominal. The TCF is also syntactically carried by noun phrase (NP) modification. This involves packaging ideological content around the nominal in an NP as pre- or post-modifiers in order to influence the audience's perception of things and people by passing arguable propositions as common assumptions by virtue of being hidden inside the 'given' part of the proposition.

The second TCF is describing actions/events/states, which concerns the choice of a verbal element to represent a situation as an action, state, event, verbalization, mental or relational process. The textual construction of a given situation will concomitantly represent the participants in it in ways that manipulate the recipient's outlook, experience and reaction. Verbal processes may be material action intentional (involving action, human agency and intentionality), material action supervention (involving action, human agency but no intentionality), material action event (involving action but non-human agents), existential process (referring to what exists), verbalizations (communicating verbiage by human or non-human sayers), mental processes (which may be of perception, cognition, or reaction), or relational process (which may be intensive, possessive, or circumstantial). This model of transitivity is drawn from Halliday's theory of grammar and is well laid out in Simpson (1993).

The third TCF is equating and contrasting, which involves the use of words and syntactic triggers to set up textual relations of equivalence and opposition. These relations are often not attested in common usage. Textual equivalence may be textually carried by synonymy, NP apposition, the copular verb and parallel structures. Textual opposition, on the other hand, is carried by different sense relations, explicit opposition, transitional opposition, comparative opposition, replacive opposition, concessive opposition, contrastives, and parallel structures. Textually created relations of equivalence and opposition are an effective way of influencing the opinions and ideological outlooks of discourse recipients by promoting or disparaging individuals, groups, or ideologies.

The fourth TCF is exemplifying, which is the provision of an example, or a selection of examples, of a certain phenomenon, and enumerating, which involves providing a complete list of the available examples. Textual carriers of exemplification include for example, for instance and to exemplify, while textual carriers of enumeration include three-part lists and phrases that suggest completeness. These two textual tools are used to either represent a given list as comprehensive or suggest incompleteness and invite the reader to think of and add other members to the list.

Prioritizing, the fifth TCF, involves changing the default focus of information in a sentence for ideological effect. The ideological priorities of text producers may be signaled by positioning information in main or subordinate clauses and by using cleft constructions, passive and adjectival transformation. This has the effect of drawing attention to or away from parts of the proposition, thereby manipulating the audience's experience of the text and reality itself by implication. 
The sixth TCF is assuming and implying. Using assumptions and implicatures, text producers tacitly assume as consensual reality propositions and relationships that are ordinarily questionable. Existential presuppositions are carried by definite NPs and possessives while logical presuppositions are carried by change of state verbs and expressions, factive verbs, cleft constructions, whquestions, iterative words, comparatives, temporal clauses and counterfactuals. Implicatures, on the other hand, are realized through flouting the maxims of the cooperative principle, viz., quality, quantity, manner and relevance.

Negating is the seventh TCF. Textual markers of negation serve to evoke a non-existent reality, which the speaker assumes to be a common belief, in order to eventually correct it. This has the effect of influencing the recipients' behavior who fear, desire, or believe the different reality evoked by negation. Negation is textually carried by negation-marking morphemes, negators with syntactic properties, and semantically inherent negators.

The eighth TCF is hypothesizing, which is carried by modal auxiliaries, modalized lexical items (verbs, adjectives and adverbs), and conditionals. The use of modalized expressions allows the text producer to express knowledge/beliefs about a proposition (epistemic modality), commitment to its truth (perception modality), its possibility/necessity (deontic modality), or desire to have it fulfilled (boulomaic modality). Modality carriers are a marker of the text producers' ideological perspective and viewpoint. They are also deployed to inspire in the recipients' mind fear, desire or belief about the propositions.

The ninth TCF concerns the representation of the speech and thoughts of others for ideological impact. There are five methods of reporting speech. These are the narrator's report of speech (NRS), narrator's report of speech act (NRSA), indirect speech (IS), free indirect speech (FIS), and direct speech (DS). Similarly, there are five methods of reporting thought, viz., narrator's report of thought (NRT), narrator's report of thought act (NRTA), indirect thought (IT), free indirect thought (FIT), and direct thought (DT). These categories represent degrees of narrator control over the speech and thoughts of others, which is manipulative of the characters represented and of the recipients' perspective.

The representation of time, space and society is the last TCF. This function involves the use of context-dependent reference to create a text world and represent time, space and relations in that world in line with the text producer's ideological preferences. Textual carriers of the function include personal, temporal and spatial deixis. Deictic projection allows text producers to draw their audience in, causing them to abandon the default deictic center and take a position from which they are more susceptible to ideologies. A schematic version of the critical stylistic framework has been developed by the researcher and presented in Figure 1.

\section{Methodology \\ 4.1 Data}

Donald Trump's social media accounts are constantly busy accounts, triggering journalistic and academic discussion and generating thousands of likes, retweets and replies. The data for this study is drawn from the pre-compiled monitor corpus 
of tweets from Trump's Twitter Archive available at www.thetrumparchive.com. It is an open-source corpus of tweets, assembled from President Trump's Twitter page @ realDonaldTrump, that includes, at the time of writing, over 56.000 tweets.

For the present study, the researcher has selected for in-depth qualitative analysis a sample of 30 tweets on a wide range of domestic and international political issues, published between 2011 and 2020. The advantage of covering this period is that it gives an insight into Trump's ideological evaluation of the parties concerned across a timeline spanning pre-political, political and presidential activity. The topics in the selected sample are both national and international, covering Palestine, Iran, Russia, North Korea, Ukraine, China, the Arab Spring, the 'China' virus, the U.S. police, the democrats, Nancy Pelosi, Joe Biden, and the US presidential elections.

\subsection{Procedure}

To achieve the study objectives, the researcher will conduct the analysis by TCFs, starting with the first TCF, and examine the way the textual triggers have been deployed to communicate, albeit insidiously, ideological evaluation and outlook on the issues represented. In the same way, the analysis will move down the list of ten textual-conceptual functions. For each TCF, the researcher will analyze three tweets. Recent tweets will cover recent issues such as the 'China' virus and the presidential elections, and older posts will address less recent events such as the Arab Spring and the Israeli-Palestinian conflict. The choice of tweets as a genre to analyze is well suited to the research purpose and analytical framework. Tweets have an enforced character count limit, which makes them shorter and more easily amenable to in-depth analysis and compels users to experiment with lexical choice, opt for reduced sentence length, and prioritize parts of the proposition. These linguistic choices, while signaling ideological priorities, constitute an interesting, and relatively unexplored, dataset to test the explanatory power of critical stylistics.

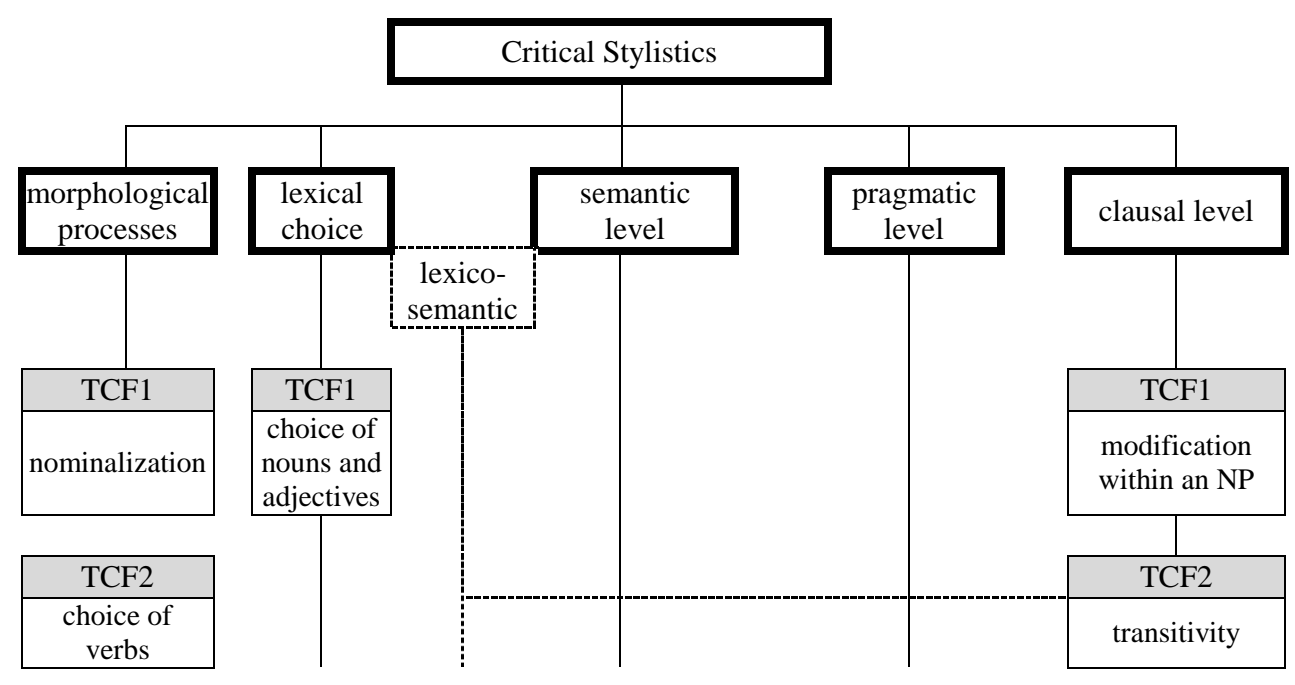



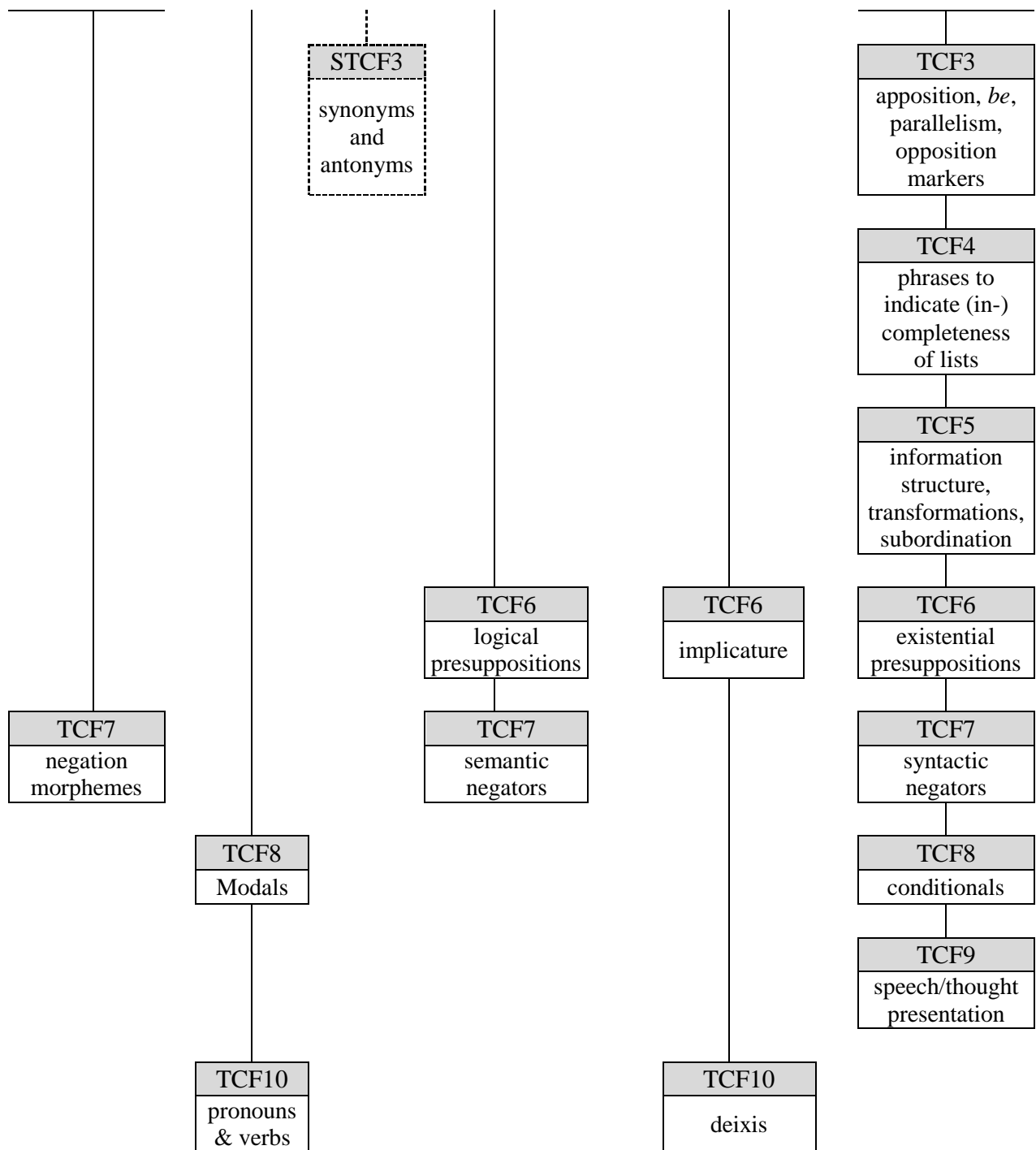

$$
\begin{gathered}
\text { TCF10 } \\
\text { pronouns } \\
\text { \& verbs }
\end{gathered}
$$

deixis

Figure 1. The critical stylistic framework

\section{Findings}

\subsection{Naming and describing}

This section examines the way Trump systematically uses naming and describing to ideological advantage in tweeting about domestic (tweets 2 and 3 ) and international events (tweet 1).

1. The Arab Spring has turned into the Islamist Winter. Our ally @ Israel is in a perilous position. We must stand behind @ Israel

(135077118693486592, Nov. 11, 2011, 10:31 PM) 
In 2011, Trump gave the Arab Spring the name "Islamist Winter" (tweet 1). The use of "Winter", as opposed to "Spring", to name the popular revolts against socio-economic grievances in totalitarian dictatorships, signals an ideological evaluation of the revolutions forming the Arab Spring. The name evokes negative associations of death to represent the hopes and aspirations of millions of Arab youths demanding social equality, political freedom and regime change. The qualification "Islamist" is used to intensify Trump's negative evaluation of what the Arab Spring has 'turned into'. The use of the adjective "Islamist" in this context and for this purpose gives the adjective a negative semantic load. Trump's naming and describing in tweet 1 is ideologically loaded and indicative of a slanted evaluative outlook on the Arab Spring and Islam.

2. Welcome to the race Sleepy Joe. I only hope you have the intelligence, long in doubt, to wage a successful primary campaign. It will be nasty - you will be dealing with people who truly have some very sick \& demented ideas. But if you make it, I will see you at the Starting Gate! (1121388967444799488, April 25, 2019, 03:22 PM)

In the context of domestic politics, specifically with reference to the 2020 presidential elections, Trump extensively used nicknaming as a strategy of attacking political opponents. His main rival, who was eventually elected the $46^{\text {th }}$ U.S. President, was nicknamed "Sleep Joe" (tweet 2), a name that Trump consistently and repeatedly used throughout the presidential race. The repeated use of this descriptive nickname is ideological. It is employed as a "tool of influence" (Tyrkkö and Frisk, 2020:111) and meant to underscore a 'weakness' in Joe Biden's profile, namely, that he is an 'old man' who is incapable of running the country, and eventually scare the American electorates' away from voting for Biden. It is worth noting that Trump used disparaging nicknames with many other individuals both nationally, such as "Crooked Hillary" for Hillary Clinton, and internationally, such as "My favorite dictator" for Egyptian President el-Sisi. An interesting linguistic account of nicknames in Trump's tweets is offered in Tyrkkö \& Frisk (2020).

3. We are United in our effort to defeat the Invisible China Virus, and many people say that it is Patriotic to wear a face mask when you can't socially distance. There is nobody more Patriotic than me, your favorite President! (1285299379746811915, July 20, 2020, 10:43 PM)

More recently, Trump has employed this TCF in relation to the on-going viral pandemic by naming Covid-19 "the China Virus" (tweet 2). Trump's labelling the deadly virus in ethnic terms is a maneuvering strategy to redirect blame onto an external agent. Trump's naming strategy signals an ideological outlook. It is racist. Trump is less concerned about the likelihood of exacerbating xenophobic feelings and inciting aggressive behavior against Chinese-Americans, and Asians in general, 
and more concerned about defecting criticism from his administration's failure to effectively respond to the pandemic.

\subsection{Describing actions/events/states}

Trump's use of transitivity about Iran (tweet 4) is also a good marker of his ideological attitude and evaluation. In this tweet, Trump uses verbs with different transitivity profiles, which signpost his outlook on the parties represented.

4. Iran is talking very boldly about targeting certain USA assets as revenge for our ridding the world of their terrorist leader who had just killed an American \& badly wounded many others, not to mention all of the people he had killed over his lifetime, including recently.... (1213593965838163968, Jan. 5, 2020, 1:52 AM)

Trump's verbal choices reflect his evaluation of Iran and Iranian leader Soleimani. Iran appears in a verbalization structure in which it assumes the sematic role of sayer (of verbiage). Trump constructs Iranian threats to the United States as verbiage and Iran as capable, at best, of only verbal threats. Soleimani is also described as a "terrorist leader", a qualification which is passed as a consensual reality by being packaged inside a nominal phrase (see TCF 1). To offer further support for the legitimacy of the U.S. action, Soleimani figures in material action intentional structures in which he is the agent of killing and wounding "many others". The United States, by contrast, does not assume agency in the tweet. Its action against Soleimani is referred to as "ridding the world", which is also structured inside a nominal and passes as a fact not open to questioning.

5. ....These THUGS are dishonoring the memory of George Floyd, and I won't let that happen. Just spoke to Governor Tim Walz and told him that the Military is with him all the way. Any difficulty and we will assume control but, when the looting starts, the shooting starts. Thank you! (1266231100780744704, May 29, 2020, 7:53 AM)

Elsewhere, Trump's transitivity choices gave away his racial views. Following the death of George Floyd under the knee of a white police officer on Monday, May 25, 2020, Trump made a tweet (tweet 5), which sparked nationwide angry protests.

In addition to naming the protestors "thugs", Trump structured the protesters in a material action intentional process in which they are agents of action that dishonors the memory of George Floyd. Trump disapproves of the protests and the protesters but takes no action to redress the cause of the protests. He appears in two verbalization processes in which he speaks to the governor and assures him of military support to curb the protests. The tweet ends with two conditional material action intentional processes that threaten the use of guns to respond to criminals' use of the protests as a cover for looting. These transitivity choices signpost Trump's ideological outlook. In addition, the absence of mental processes and the absence 
of action processes aimed at police reform signal both Trump's lack of empathy and lack of desire to take action to redress racial discrimination.

6. China has caused great damage to the United States and the rest of the World! (1280116392990253056, July 6, 2020, 3:28 PM)

Trump's choice of verbs and patterns of transitivity also sustains his ideological outlook on China (tweet 6). To implicate China in the disaster that has befallen the world, Trump chose a material action intentional verb whose agent is "China" and whose goal is "the United States and the rest of the world". This transitivity choice, along with the fact that it appears in a single level of subordination in which China occupies the highest level of structure (see TCF 5) serves to foreground China's agency and intentionality in causing the damage.

\subsection{Equating and contrasting}

In this section, we will be looking at Trump's textually constructed relations of synonymy and opposition, which are ideologically loaded. The three tweets to analyze here are from U.S. domestic politics.

7. Colin Powell, a real stiff who was very responsible for getting us into the disastrous Middle East Wars, just announced he will be voting for another stiff, Sleepy Joe Biden. Didn't Powell say that Iraq had "weapons of mass destruction?" They didn't, but off we went to WAR! (1269634983687315457, June 7, 2020, 5:19 PM)

In tweet 7, Trump uses noun phrase apposition to construct textual relations of synonymy. He equates Colin Powell with stiffness and failure - an ideological evaluation that evades scrutiny by being packaged inside an appositive NP. Later in the tweet, Trump equates Joe Biden with Colin Powel. The equation of Biden with Powell serves to transfer the set of negative evaluations formerly equated with Powel to Biden. This textually constructed synonymy (Biden is another Powel) is ideologically loaded. Trump seeks to win the elections by inciting fear among electorates about the prospect of going to war should Biden get elected.

\section{LAW \& ORDER, NOT DEFUND AND ABOLISH THE POLICE. The Radical Left Democrats have gone Crazy! (1269970808329437185, June 8, 2020, 3: 33 PM)}

In the second tweet in this group, Trump constructs a textual opposition between national security and the democrats' call to defund the police (tweet 8). Using replacive opposition, Trump constructs an appositional syntactic frame in which law and order stand in opposition to the democrats' call for a new model of community-led public safety. In this frame, defunding the police does not equate with reallocating funds away from policing to social services to reduce the need for police intervention. Instead, it is constructed in opposition to law enforcement and 
maintaining social order. The replacive opposition serves to reflect Trump's political ideology vis-à-vis the democrats and the Black Lives Matter movement.

9. Sleepy Joe Biden is just a Trojan Horse for the Radical Left Agenda. He will do whatever they want! (1288436755646099459, July 29, 2020, 2:30 PM)

Trump resorts to another scare tactic via textual equation in tweet 9 . He makes another equation that constructs Biden as a 'conduit' for the radical left agenda. Trump tweets that Joe Biden is "just a Trojan Horse for the Radical Left Agenda". The textually constructed relation of synonymy is employed for ideological effect. It underscores Biden's lack of agency, further delegitimizes Joe Biden as a candidate for U.S. president, and scares the American voters into voting for Donald Trump.

\subsection{Exemplifying and enumerating}

Trump also uses exemplification and enumeration to ideological effect. He uses exemplification to invite the audience to think of other possible members of the list (tweet 12) and uses three-part lists to suggest comprehensiveness of, and familiarity with, the list of members (tweets 10 and 11).

10. Russia has more warheads than ever, $N$ Korea is testing nukes, and Iran got a sweetheart deal to keep theirs. Thanks, @HillaryClinton. (780594918616162304, Sep 27, 2016, 5:28 AM)

11. Russia, Syria, and Iran are killing, or on their way to killing, thousands of innocent civilians in Idlib Province. Don't do it! Turkey is working hard to stop this carnage. (1210220021433208832, Dec 26, 2019, 6: 25 PM)

In the first two tweets, Trump uses three-part lists to suggest familiarity with the enemies of the Syrian people and of US nuclear enemies. Trump capitalizes on the audience's intuitive association of three-part lists with comprehensiveness in order to implicate Hillary Clinton in serving the interests of 'all' US nuclear enemies (tweet 10), and to implicate Russia, Iran and the Syrian regime as 'the' killers of innocent civilians in Idlib province (tweet 11). The former three-part list is used to project Trump as aware of U.S. nuclear enemies and project Hillary, by contrast, as jeopardizing American national security. Trump, at the time of tweeting, was running for President and this tweet was intended to influence Americans' evaluation and, eventually, their voting behavior. The latter three-part, on the other hand, list serves to suggest Trump's knowledge about the parties involved in the Syrian conflict and to project him in proximity to the suffering of the Syrian people. 
12. With Votes in the House tomorrow, Democrats want to make it harder for Presidents to defend America, and stand up to, as an example, Iran. Protect our GREAT COUNTRY! (1222670610867916804, Jan 30, 2020, 2:59 AM)

In tweet 12, Trump uses exemplification as a scare tactic. In trying to win votes in the House, Trump represents the democrats on the side of American enemies. He brings up Iran as one example, suggesting a long list of enemies and inviting the audience to envisage other potential members of the list. This has the ideological effect of constructing the democrats as a threat to American interests and national security.

\subsection{Prioritizing}

Trump's ideological priorities are signposted by the levels of subordination in his tweets. He calls to the highest level of structure arguments about which he has strong opinions (tweet 14) and subordinates at lower levels arguments he wishes to pass unexamined (tweets 13 and 15).

\section{Again, the President of Ukraine said there was NO (ZERO) PRESSURE PUT ON HIM BY ME. Case closed! (1178650939374424067, Sep 30, 2019, 3"40 PM)}

Trump uses prioritization effectively in reporting on the Ukraine scandal. He uses a passive transformation to relegate his own agency to the lowest level of structure (tweet 13). The passive transformation allows Trump to promote to the highest level of subordination the verbalization process by the President of Ukraine. The reported verbiage emphasized the absence of any pressure exercised on the President of Ukraine. Trump's agency appears at the lowest level of subordination, making it less visible. Trump employs prioritization effectively to foreground verbiage and background action, especially action by him, which may be viewed as an attempt to re-orient public perception of the Trump-Ukraine scandal.

\section{IRAN WILL NEVER HAVE A NUCLEAR WEAPON! (1214197038063243266, Jan 6, 2020, 5:48 PM)}

In reference to Iran (tweet 14), Trump's ideological priorities are very clear. His tweet is structured to reflect what he prioritizes. In addition to capitalizing all the letters in the tweet, which Trump himself describes as his way of showing emphasis, the tweet has a single level of subordination, which further underlines Trump's clarity of intentions. In this tweet, Trump preserves the default information structure in which "IRAN" is the given information and the propositional content is that it "WILL NEVER HAVE A NUCLEAR WEAPON". The use of no complex levels of subordination, along with the absence of any transformations, makes the message very clear, and the capital letters make it loud. 
15. Ted Wheeler, the wacky Radical Left Do Nothing Democrat Mayor of Portland, who has watched great death and destruction of his City during his tenure, thinks this lawless situation should go on forever. Wrong! Portland will never recover with a fool for a Mayor.... (1300170576515026945, Aug 30, 2020, 11:36 PM)

In reference to other actors, Trump uses multiple levels of subordination in order to prioritize certain parts of his propositions and make others less salient and therefore less amenable to debate. Trump's main proposition in tweet 15 is that Ted thinks that the situation should go on forever. Embedded within this proposition are a number of potentially contentious evaluative propositions about Ted Wheeler. Trump draws attention away from his ideological evaluation of Ted by structuring it in the given part of the proposition. His qualification of Ted as "wacky", "Radical", "Left", "Do Nothing Democrat Mayor" who "has watched great death and destruction of his City", as well as the qualification of the situation as "lawless" are subordinated to the main proposition, making them difficult to contest. These ideological evaluations are passed as though they were a consensual reality by being packaged within the main proposition.

\subsection{Assuming and implying}

Trump is generally quite explicit about what he wants to communicate. His use of assumptions and implicatures, therefore, have powerful ideological effects, as we shall see in the following three tweets, which are all thematically related.

16. If the Palestinians want statehood then why are they run by the terrorist group Hamas? (108306883194011648, Aug 30, 2011, 1:35 AM)

Trump's use of the wh-question word "why" (tweet 16) logically presupposes that Hamas 'runs' the Palestinians. He packages the ideological qualification "terrorist" inside the nominal headed by Hamas, which has the ideological effect of constructing the Palestinian people as run by terrorists. This construction is passed an assumption that is hard to contest by being 'sneaked' within the definite noun phrase.

17. The Palestinian terror attack today reminds the world of the grievous perils facing Israeli citizens....continued (785245066881216512, Oct 10, 2016, 1:26 AM)

In this tweet (tweet 17), Trump's use of presupposition sustains his ideological evaluation of the parties in the Palestinian-Israeli conflict. He qualifies the terror attack as "Palestinian" and structures this qualification inside a definite NP in order to pass it as an assumption that is hard to question. He also uses the iterative word "reminds" to logically presuppose that the world is already aware of 
the "grievous perils facing Israeli citizens". These perils are themselves logically presupposed by virtue of being structured inside a definite noun phrase.

18. ....To the Gazan people - these terrorist acts against Israel will bring you nothing but more misery. END the violence and work towards peace - it can happen! (1125191945654099968, May 6, 2019, 3:13 AM)

In the last example (tweet 18), Trump addresses the "Gazan people" who he accuses of carrying out "the terrorist acts against Israel". Trump's use of the iterative word "more" in "will bring you more misery" logically presupposes his awareness of the misery in which the Gazans are living. The iterative is also a threat with "more of the same'. Trump is threatening the Gazan people with more of the misery he is aware they are living in but not addressing.

\subsection{Negating}

Negation communicates an actual absence but has the potential to suggest a possible presence. Trump uses negation to suggest possible realities in order to influence the ideology and behavior of the American voters (tweet 19).

19. The Democrats would not have BANNED travel from heavily infected China, especially so early, therefore, far more people would have died. Corrupt Joe Biden now admits this!!! (1280210947014119424, Jul 6, 2020, 9:44 PM)

The negated, and embedded, viewpoint creates a hypothetical reality for the American voters to fear. It is a possible world in which the Democrats do not ban travel from China and in which more people die as a consequence. Using negation, Trump constructs this possible reality to evoke a possible world that scares the American electorates and influences their voting decisions.

20. No, Radical Left anarchists, agitators, looters or protesters will not be knocking down or harming the Washington Monument, the Lincoln or Jefferson Memorials, or just about any other Federal Monument or Statue. If they even try, an automatic 10 years in prison. Sorry! (1282291265661472771, Jul 12, 2020, 3:30 PM)

The above example is a tweet on the protests following the killing of George Floyd. Trump was growing impatient with the nationwide protests and the rioting that accompanied the protests. In this tweet, he uses negation to project a possible reality in which protesters are knocking down national monuments (tweet 20). This construction of this hypothetical reality serves to legitimize the use of violence against the "looters or protestors". 
21. Must know Election results on the night of the Election, not days, months, or even years later! (1288933078287745024, Jul 30, 2020, 11:22 PM)

The U.S. presidential elections in 2020 took place amid concerns for safety over the Covid-19 pandemic. Trump was running for reelection and he attempted to influence the course of the elections (tweet 21). Trump's embedded viewpoint in the tweet, created via negation, evokes a possible reality in which election results are manipulated and the real results come out years later. As the election results unfold, Trump's tweets assert his outlook in this regard. He refuses to accept the result and concede defeat, and continues to make claims about election fraud as a result of mail-in voting. This is the scenario created via negation months ahead of the election in the tweet.

\subsection{Hypothesizing}

In expressing his views, Trump sometimes makes categorical, unmodalized, propositions and at times modalizes his expressions to communicate his views on the desirability or possibility of something taking place. This section focuses on tweets that are related in theme and time, specifically on Trump's relationship with China.

In the first two tweets, Trump deploys modality carriers to manipulate his followers' experience of facts and the world, and project himself favorably in an attempt to influence the American voters' evaluation and behavior.

22. We are doing very well in our negotiations with China. While I am sure they would love to be dealing with a new administration so they could continue their practice of "ripoff USA"(\$600 B/year),16 months PLUS is a long time to be hemorrhaging jobs and companies on a long-shot.... (1168874291376656384, Sep 3, 2019, 4:12 PM)

23. ....And then, think what happens to China when I win. Deal would get MUCH TOUGHER! In the meantime, China's Supply Chain will crumble and businesses, jobs and money will be gone! (1168874292626501633, Sep 3, 2019, 4:12 PM)

Trump starts tweet 22 with an unmodalized assertion in reference to his own achievements in negotiations with China. Following this, he uses strong epistemic modality "I am sure" to suggest 'knowledge' about China's foreign policy and its dangerous encroachment on the economy and future of the United States. Trump also uses the iterative verb "continue" to suggest previous economic losses to China. This has the ideological effect of asserting his 'knowledge' of the Chinese foreign policy, inspiring a sense of fear for the American economy, and American lives by implication, and enhancing his own chances of winning the upcoming presidential elections. 
In the other tweet (tweet 23), Trump uses the high value epistemic modality marker "would" to present the negative effects on China of Trump's winning a second residential term. The use of high value epistemic modality projected Trump as speaking from a position of knowledge about US-China relations and about the Chinese economy. Trump capitalizes on the anti-China sentiments that played out during the Covid-10 pandemic in an attempt to win more voters and enhance his chances of winning the elections. When the number of deaths from Corona Virus soared in the United States, Trump sought to divert attention from the rising number of fatalities and the affected economy to an external agent, viz., China (tweet 24).

24. China has caused great damage to the United States and the rest of the World! (1280116392990253056, Jul 6, 2020, 3:28 PM)

This particular tweet is reproduced from tweet 6. Previously, we argued that Trump used a single level of subordination in order to implicate China and foreground its agency in the spread of the pandemic. Trump's choice of a categorical, unmodalized, assertion in the tweet is consistent with his ideological outlook. This absence of any modality markers is a significant choice because it presents Trump's proposition as though it was a fact and imparts a sense of absolute certainty about its content.

\subsection{Presenting others' speech and thoughts}

Trump also gives himself the freedom to manipulate the speech and thoughts of others. Manipulating others' words and/or thoughts has the effect of exercising varying degrees of control over not only the words and thoughts reported but also over the perception of the audience of the events and entities represented.

25. @ thehill @ realDonaldTrump The people of NH know what the American people know: Trump is the only one with any CLUE about how to fix things" (626037537350524928, Jul 28, 2015, 5:32 PM)

In tweet 25, Trump uses indirect thought (IT) presentation to report the thoughts of the people of New Hampshire and all Americans. By giving himself access to the minds and cognition of all Americans, Trump asserts his authority and presents his own judgment as if it was consensual knowledge.

26. Nancy Pelosi just stated that "it is dangerous to let the voters decide Trump's fate.” @FoxNews In other words, she thinks I'm going to win and doesn't want to take a chance on letting the voters decide. Like Al Green, she wants to change our voting system. Wow, she's CRAZY! (1196658170984357888, Nov 19, 2019, 8:15 AM)

27. Crazy Nancy Pelosi said I made a mistake when I banned people from infected China from entering the U.S. in January. Tens of thousands 
of lives were saved, as she danced in the Streets of Chinatown (SF) in late February. Biden agreed with her, but soon admitted that I was right! (1287371355332190208, Jul 26, 2020, 3:57 PM)

The other two tweets (tweets 26 and 27) are on the US speaker of the House of Representatives, Nancy Pelosi. In tweet 26, Trump uses direct speech (DS) to present a distorted paraphrase of Pelosi's words as if they were her own words. After attributing a distorted statement to her through DS, Trump uses direct thought (DT) to report what Pelosi thinks. By reporting Pelosi's wishes, Trump's control of Pelosi is complete. He manipulates her speech and thoughts in order to influence the recipients' evaluation of Pelosi. In tweet 27, Trump exercises further freedom in reporting Pelosi's words and thoughts. He uses indirect speech (IS) to falsely attribute a statement to Pelosi to implicate her in mismanaging the Covid-19 pandemic. He also reports an act that never took place, viz., dancing in the streets of Chinatown in San Francisco, in order to construct Pelosi as irresponsible and unmindful of the sufferings of Americans. Trump also uses the narrator's report of speech act (NRSA) in "Biden agreed with her" to implicate Joe Biden as well. He takes complete freedom in misrepresenting Pelosi and Biden in order to construct democrats as unworthy of public trust and construct himself as the trusted guardian by contrast.

\subsection{Presenting time, space and society}

By default, text recipients occupy the deictic center and can project deictically in response to textual demands. Trump exploits this ability for ideological purposes in addressing the Gazan people in tweet 28 (reproduced from tweet 18 above).

28. .... To the Gazan people - these terrorist acts against Israel will bring you nothing but more misery. END the violence and work towards peace - it can happen! (1125191945654099968, May 6, 2019, 3:13 AM)

In line with Trump's ideological evaluation outlined earlier (tweet 18), he uses the proximal pronoun "these" in "these terrorist acts" in order to project himself in the deictic center and in proximity to the Israelis and sharing their pain and suffering. He also uses the preposition of movement "towards" in asking the Gazan to "work towards peace". This serves to construct the Gazan people as directionally opposite to peace.

29. Suburban voters are pouring into the Republican Party because of the violence in Democrat run cities and states. If Biden gets in, this violence is "coming to the Suburbs", and FAST. You could say goodbye to your American Dream! (1303339826016550912, Sep 8, 2020, 5:30 PM) 
At the domestic level (tweet 29), Trump's use of deictic expressions carries his outlook on the democrats in anticipation of the 2020 presidential elections. His use of a spatial deictic pronoun and a verb of movement in "this violence" and "coming to the Suburbs" constructs him as sharing a physical space with Suburbans and projects him in proximity to their concern for their lives. At the end of the tweet, Trump uses a second person pronoun in "You should say goodbye to your American Dream" in order to distance himself from the gloomy future awaiting Suburbans should Biden win the elections. They will face the consequences on their own.

30. Pelosi \& Schumer have no interest in making a deal that is good for our Country and our People. All they want is a trillion dollars, and much more, for their Radical Left Governed States, most of which are doing very badly. It is called a BAILOUT for many years of bad Dem Mgmt! (1289282585718190080, Jul 31, 2020, 10:31 PM)

In the last tweet, also in reference to the democrats, Trump uses inclusive deictic pronouns, as in "our Country" and "our People", which are used to conceptualize a group identity that Trump shares with the American people. In contrast, the democrats are referred to in the exclusive third-person deictic pronoun "they". This dichotomy, created via deictic pronouns, has the ideological effect of not only representing Trump's democratic rivals as excluded from the group identity but also constructing them in opposition to it and to American national interests (tweet 30).

\section{Conclusions}

Analysis of the data has uncovered a layer of meaning hidden behind Trump's apparently simple rhetoric that hides ideological perspective and manipulative practices. Trump uses naming and transitivity patterns as tools of influence to implicate his domestic and international political rivals. His ideological outlook on political issues is signposted by textual patterns of subordination and is constructed in lexico-semantic relations of equivalence and contrast as well as in pragmatic assumptions and implications. Trump also uses listing to project his political knowledge and competence and systematically hypothesizes nonexistent versions of reality for ideological impact via negation and modality. In addition, Trump's political rhetoric exhibits a tendency to construct opponents unfavorably by misrepresenting their speech and thoughts, both directly and indirectly. He also manipulates the discourse recipients' ability for deictic projection in order to cause them to adopt his own textually constructed ideological perspective.

The study is an extension of the range of applications of critical stylistics. The critical stylistic framework has been applied in the literature to the analysis of the textual representation of individuals and groups in political statements (e.g., Alaghbary, 2014, 2019; Abeed 2017), the construction of socio-political ideologies in the media (e.g., Matthew, 2009; Hermeston, 2017), and the depiction of fictional worlds in non-canonical literary texts (e.g., Ibrahim, 2018). The present study has extended the text types analyzed to include microblogging channels, which are 
primarily used for social communication. In doing this, the study achieves two goals. Firstly, it offers an addition to the growing body of literature on the use of microblogging tools as media for political communication. This trend, though relatively recent, is attracting increasingly more scholarly attention because of the widespread use of social media for political communication worldwide. Secondly, it offers empirical evidence of the descriptive power of the critical stylistic framework. The ten TCFs have offered revealing insights about the way Trump strategically deploys the resources of language to influence and ideologically manipulate his followers' experience of reality.

The use of microblogging platforms by high-profile politicians to negotiate issues of public interest, run domestic political affairs, and to engage in diplomatic interactive communication with foreign leaders is a trend worthy of further research and investigation. This is particularly interesting with reference to Twitter in which message brevity enforces simplicity, "structurally disallows the communication of detailed and sophisticated messages" (Ott, 2016:60), and encourages "uncivil" and "dark, degrading, and dehumanizing discourse" (62).

Gibreel Sadeq Alaghbary

Department of English, College of Sciences and Arts, Unaizah,

Qassim University, Saudi Arabia

Taiz University, Yemen

ORCID Number: 0000-0002-8531-2913

Email: g.alaghbary@qu.edu.sa

\section{References}

Abeed, Manal. (2017). News representation in times of conflict: A corpus-based critical stylistic analysis of the Libyan revolution. Unpublished $\mathrm{PhD}$ Thesis, University of Huddersfield, Huddersfield, UK.

Ahmadian, Sara, Sara Azarshahi and Delroy L. Paulhus. (2017). 'Explaining Donald Trump via communication style: Grandiosity, informality, and dynamism'. Personality and Individual Differences, 107:49-53. doi: 10.1016/j.paid.2016.11.018

Alaghbary, Gibreel Sadeq. (2019). 'Ideological positioning in conflict: The United States and Egypt's domestic political trajectory'. In Matthew Evans, Lesley Jeffries and Jim O'Driscoll (Eds.), The Routledge Handbook of Language in Conflict, 83-102. New York: Routledge.

Alaghbary, Gibreel Sadeq. (2014). 'The United States reaction to the Arab Spring: A critical stylistic analysis'. Journal of Language Aggression and Conflict, 2 (1):151-175. doi: $10.1075 /$ jlac.2.1.06ala 
Bimber, Bruce. (2014). 'Digital media in the Obama campaigns of 2008 and 2012: Adaptation to the personalized political communication environment'. Journal of Information Technology \& Politics, 11 (2):130-150. doi: 10.1080/19331681.2014.895691

Clark, Isobelle and Jack Grieve. (2019). 'Stylistic variation on the Donald Trump Twitter account: A linguistic analysis of tweets posted between 2009 and 2018'. PLoS ONE, 14 (9): e0222062, doi: 10.1371/journal.pone.0222062

Elayan, Suzanne, Martin Sykora and Tom Jackson. (2020). 'His tweets speak for themselves: an analysis of Donald Trump's Twitter behaviour'. The International Journal of Interdisciplinary Civic and Political Studies, 15 (1):11-35. doi: 10.18848/2327-0071/CGP/v15i01/11-35

Enli, Gunn. (2017). 'Twitter as arena for the authentic outsider: exploring the social media campaigns of Trump and Clinton in the 2016 US presidential election'. European Journal of Communication, 32 (1):50-61. doi: $\underline{10.1177 / 0267323116682802}$

Fairclough, Norman. (1989). Language and power. London: Longman.

Garcìa, Tomás Mena. (2018). 'Donald J. Trump: A critical discourse analysis'. Revista Estudios Institucionales, 5 (8):47-73. doi: 10.5944/eeii.vol.5.n.8.2018.21778

Gorss, Justin H. and Kaylee T. Johnson. (2016). 'Twitter taunts and tirades: Negative campaigning in the age of Trump'. Political Science \& Politics, 49 (4):748-754. doi: 10.1017/S1049096516001700

Grice, Herbert Paul. (1975). 'Logic and conversation'. In Peter Cole and Jerry L. Morgan, J. (Eds.), Syntax and semantics, Vol 3, Speech Acts, 41-58. New York: Academic Press.

Hermeston, Rod. (2017). 'Towards a critical stylistics of disability'. Journal of Language and Discrimination, 1 (1):34-60. doi: 10.1558/jld.34022

Holubnycha, Liudmyla, Ilona Kostikova, Tetiana Besarab, Yevheniia Moshtagh, Yuliia Lushchyk and Ogla Dolgusheva. (2020). 'Semantic and structural aspects of Donald Trump's neologisms'. Postmodern Openings, 11 (2):43-59. doi: 10.18662/po/11.2sup1/178

Ibrahim, Mahmood. (2018). The construction of the speaker and fictional world in The Small Mirrors: Critical stylistic analysis. Unpublished $\mathrm{PhD}$ thesis, University of Huddersfield, Huddersfield, UK.

Jeffries, Lesley. (2015). 'Critical stylistics'. In Violeta Sotirova (Ed.), The Bloomsbury Companion to Stylistics, 157-176. London: Bloomsbury.

Jeffries, Lesley. (2014). 'Interpretation'. In Peter Stockwell and Sara Whiteley (Eds.), The cambridge handbook of stylistics, 469-86. Cambridge: Cambridge University Press.

Jeffries, Lesley. (2013). 'Critical stylistics'. In Michael Burke (Ed.), The Routledge handbook of stylistic, 408-420. London: Routledge.

Jeffries, Lesley. (2010). Critical stylistics. Basingstoke: Palgrave.

Kayam, Orly. (2018). 'The readability and simplicity of Donald Trump's language'. Political Studies Review, 16 (1):73-88. doi: $\underline{10.1177 / 1478929917706844}$ 
Lim, Merlyna. (2017). 'Freedom to hate: social media, algorithmic enclaves, and the rise of tribal nationalism in Indonesia'. Critical Asian Studies, 49 (3):411-427. doi: $10.1080 / 14672715.2017 .1341188$

Olimat, Sameer Naser. (2020). 'Words as powerful weapons: Dysphemism in Trump's Covid-19 speeches'. 3L: The Southeast Asian Journal of English Language Studies, 26 (3):17-29. doi: 10.17576/3L-2020-2603-02

Ott, Brian L. (2016). 'The age of Twitter: Donald J. Trump and the politics of debasement'. Critical Studies in Media Communication, 34 (1):59-68. doi: 10.1080/15295036.2016.1266686

Matthew, Evans. (2009). A critical stylistic analysis of the textual meanings of 'feminism', 'feminist(s)' and 'feminist' in UK national newspapers, 20002009. Unpublished PhD thesis, University of Huddersfield, Huddersfield, UK.

Nahajec, Lisa. (2009). 'Negation and the creation of implicit meaning in poetry'. Language and Literature, 18 (2):109-127. doi: $\underline{10.1177 / 0963947009105340}$

Semino, Elena and Mick Short. (2004). Corpus stylistics: Speech, writing and thought presentation in a corpus of English writing. London: Routledge.

Simpson, Paul. (1993). Language, ideology and point of view. London: Routledge.

Tyrkkö, Jukka and Irina Frisk. (2020). 'Crooked Hillary, lying' Ted, and failing New York Times: Nicknames in Donald Trump's tweets'. In Ulrike Schneider and Matthias Eitelmann (Eds.), Linguistic inquiries into Donald Trump's language, 109-129. London and New York: Bloomsbury.

Wang, Yaqin and Haitao Liu. (2018). 'Is Trump always rambling like a fourthgrade student? An analysis of stylistic features of Donald Trump's political discourse during the 2016 election'. Discourse and Society, 29 (3):299-323. doi: $\underline{10.1177 / 0957926517734659}$ 